\title{
Gymnastik og sport i den danske skole ca. 1900-1960
}

Af Per Jørgensen

Den generelle modernisering af det danske samfund, ${ }^{1}$ der fandt sted fra slutningen af det 19. århundrede frem til årene efter 2. verdenskrig, kom også til udtryk indenfor såvel fritidsidrætten som skoleidrætten.

I løbet af første halvdel af dette århundrede blev skoleidrætten efterhånden udbredt til begge $k \varnothing n$ og hele undervisningssystemet fra folkeskole til gymnasium, samtidig med at undervisningen i stigende grad blev udført af lærere, der var ensartet uddannet på seminarium eller universitet. I samme periode fandt en $\varnothing$ get centralisering af beslutninger og vedtagelser om skolegymnastik sted, og kontrol med lokale myndigheder blev almindelig. Denne bureaukratisering og standardisering af skoleidrætten omfattede såvel indhold som rammer. Fagets formål og begrundelse blev ligeledes ændret i perioden. Århundredskiftet bragte et farvel til gamle nationale og militære begrundelser for skolegymnastikken. De blev afløst af sundhedsmæssige og fysiologiske begrundelser. ${ }^{2}$ Gamle autoriteter var væk, men nye var dukket op. I samfundet var præsten og officeren allerede blevet afløst af lægen og ingeniøren som identifikationsobjekter. ${ }^{3}$ Også i den nye skolegymnastiks etablering havde lægen en nøglerolle, og i gymnastiksalen var gymnastiklæreren ingeniør. Her konstruerede han et gymnastikprogram og dirigerede ideelt set sine elever frem mod fysisk og mental sundhed ved hjælp af velvalgte, velberegnede og veldocerede $\varnothing$ velser.
Skoleidrættens historie i perioden er beskrevet tidligere. Det hævdes som oftest, at den gymnastik, der blev indført i de danske skoler for såvel piger som drenge ved århundredskiftet, var »svensk gymnastik «. Den blev indført på bekostning af »dansk « gymnastik, der tabte »slaget«, og sport der blev bekæmpet. Indførelsen af den nye gymnastik slog hurtigt igennem og havde en dominerende indflydelse frem til ca. 1960. I det følgende vil nogle af disse antagelser blive diskuteret. ${ }^{4}$

Der vil blive argumenteret for, at »svensk gymnastik « først og fremmest var et princip og ikke en aktivitet, at mange elever, især piger, slet ikke har haft skoleidræt før efter 2 . verdenskrig, at skoleidrætten især på landet i store dele af perioden ofte var en parodi, og at der blev dyrket betydelig mere sport end tilsigtet. Desuden vil, det tilsyneladende paradoksale forhold, at gymnastiktilhængerne og sportstilhængerne-så uenige de end syntes at være i deres respektive argumentation - havde helt de samme grundsynspunkter m.h.t. skoleidrættens muligheder og fordele, blive diskuteret.

\section{»Svensk gymnastik« eller »Dansk gymnastik«?}

I 1887 nedsatte Kirke- og Undervisningsministeriet den såkaldte »Lille Gymnastikkommission«, som senere blev udvidet til 
den »Store Gymnastikkommission«, der afsluttede sit arbejde i 1899. Begge kommissionerne skal ses som et led i en moderniseringsbestræbelse af skolen. Som direkte konsekvens af dette arbejde og kommissionens flertals anbefalinger, blev den danske skoleidræt omorganiseret, undervisningen sat i faste rammer og et nyt fagmål med et nyt indhold indført. ${ }^{5}$ I kommissionen var der et flertal af tilhængere af »svensk « gymnastik, også kaldet Linggymnastik, der via højskolerne og gymnastik- og skyttebevægelsen på landet havde vundet indpas siden midten af 1880-erne. ${ }^{6}$ En ny videregående idrætslæreruddannelse blev oprettet i 1898 i København ved dannelsen af Statens Et-aarige Gymnastikkursus, (»Gymnastikkurset«). ${ }^{7}$ Tilhængeren af svensk gymnastik - den »Store Gymnastikkommissions « sekretær - K.A. Knudsen blev forstander på »Gymnastikkurset $~^{8}{ }^{8}$ Indholdet i den nye idrætsuddannelse og i undervisningen i skolen blev beskrevet i Gymnastikkommissionens bøger først og fremmest i den autoritative lærebog fra 1899: »Haandbogen i Gymnastik « (»Haandbogen«), der blev grundbog for skoleidrætten frem til midten af 1920-erne. Denne bog indeholder også et fyldigt afsnit om leg og sport.

Det formelle udgangspunkt for reformarbejdet ved århundredskiftet var skolereformen i 1899: »Lov om forskellige forhold vedrørende Folkeskolen«, der blev revideret i 1904 samt »Loven af 1903 om højere Almenskoler«. Ved reformerne omkring århundredskiftet fik gymnastikken især forstået som svensk gymnastik - en særstilling i skoleidrætten. Denne særstilling gav sig bl.a. udtryk i, at alle aktiviteter i princippet var gymnastik, idet faget blev opdelt i »egentlig gymnastik « (især stillingsgymnastik) og »anvendt gymnastik « (leg og boldspil). Ved den næste skolere- form i 1937 mistede gymnastikken i princippet sin særstilling. Der blev indført en formel ligestilling mellem gymnastik og leg for de yngre klasser og gymnastik og idræt for de ældre. Gymnastik, herunder formgivende $\emptyset$ velser, fyldte dog mest i den samlede årsplan. ${ }^{9}$

Det er blevet påstået, at »Haandbogen « $\mathrm{i}$ sig selv var en sejr for den svenske gymnastik. ${ }^{10}$ Det kan man ikke sige, idet udformningen snarere var et udtryk for et kompromis mellem forskellige fløje i den kommission, der stod bag bogen. Kompromisset gik ud på at $\emptyset v e l s e s i n d h o l d e t ~ i ~$ stort omfang forblev traditionelt, d.v.s. »danskt «, mens principperne bag udførelsen skulle være »svenskt«. Det sidste var langt det vigtigste for tilhængerne af den svenske gymnastik. Her var et logisk og funktionelt skelet, der kunne bruges i skolegymnastikken. Øvelserne i det oprindelige »svenske« system - syntes selv kommissionens stærke formand - professor Kristian Kromann, der var tilhænger af svensk gymnastik - var noget kedelige. Han gik derfor ved $\varnothing$ velsesvalget - man skal dog ikke også frakende ham en vis taktisk sans i forsøget på imødegå den »danske« fløj ind for at bevare og udbygge den eksisterende »danske « gymnastik. ${ }^{11}$ Resultatet blev, som det blev formuleret $\mathrm{i} \gg$ Haandbogen «, at kommissionen havde: »først og fremmest $\varnothing$ st af vort eget tidligere Øvelsesforraad «. Hvilket altså vil sige, at det gamle »danske« systems $\varnothing$ velser blev anvendt. Nogle øvelser fra det svenske repertoire blev dog også valgt, ligesom helt nye blev konstrueret, hed det i »Haandbogen «. De $\emptyset v e l s e r$, der skønnedes bedst muligt at kunne opdrage eleverne, blev valgt. Opdragelseselementet var nemlig det vigtigste i skolegymnastikken. Allerede i bogens forord blev der advaret mod, at lystprincippet blev gjort til drivkraft i undervisningen. 
Gymnastiklæreren, blev det påpeget, skulle nemlig ikke kun undervise i det, der umiddelbart tiltalte eleverne mest, hvilket angiveligt var leg og boldspil. Der skulle især undervises i gymnastik. Det vigtigste var nemlig »ikke at more, men at opdrage « eleverne. ${ }^{12}$

Skolegymnastikkens påståede »svenskhed «, fra århundredskiftet og fremover herhjemme, er således først og fremmest et princip og ikke nødvendigvis et indhold. Det skelet af svenske principper $\emptyset$ velserne blev hængt op på, kan sammenfattes således: ${ }^{13}$

* Alle øvelser skulle være fysiologisk værdifulde.

* Enhver øvelse krævede en modøvelse. (Modøvelsen til »Bøjning bagud « var f.eks. »Bøjning fremad «).

* Øvelser skulle være ordnede efter deres virkning på organismen, ikke efter »benyttede Redskaber eller andre udvortes Hensyn «.

* Gymnastikken skulle være en afrundet helhed. Først stigning fra lettere til sværere $\emptyset$ velser. Siden dalen til »afsluttende, beroligende $\emptyset$ velser $«$.

* Øvelserne skulle fortrinsvis være fællesøvelser uden brug af redskaber.

* Anvendtes enkeltmandsøvelser d.v.s. redskabsøvelser - skulle så mange elever som muligt være beskæftiget ad gangen og der skulle arbejdes $\mathrm{i} »$ troppe $\ll$.

* I undervisningen skulle anvendes »Timeseddel « (også kaldet »Dags$\emptyset$ velse $\ll)$.

* Øvelser skulle ledes/dirigeres og kommando anvendes.

Og når det således ofte er blevet hævdet, at den svenske gymnastik gik sin sejrsgang $\mathrm{i}$ den danske skole efter århundredskiftet, er der - i det omfang udsagnet overhovedet er sandt - altså især tale om svensk form og dansk indhold.

Det må dog medgives, at de »danske « $\emptyset$ velser, der blev valgt, var $\emptyset$ velser, der især passede til de svenske principper. Det medførte en del debat i samtidens gymnastikkredse, ikke mindst hvad de såkaldte »behændighedsøvelsers« placering angik. ${ }^{14}$ Men eftertidens indtryk af at den svenske gymnastik kun var en stillingsgymnastik med fællesøvelser helt uden brug af behændighedsøvelser og for den sags skyld også redskaber er overdrevent. På »Gymnastikkurset «, hvor den nye gymnastik skulle udbredes i form af årskurser, månedskurser og ugekurser blev der nemlig også undervist i såvel behændighedssom redskabsøvelser. »Haandbogen« indeholdt f.eks. hovedspring, kraftspring og møllevending, og der blev også brugt en hel del redskaber i den gymnastik, årskursisterne blev undervist i. Ikke kun ribbe, bom, buk og plint, men også så - i en skolesammenhæng - komplicerede redskaber som reck og barre. ${ }^{15}$ Når redskabsøvelser alligevel havde det svært i skoleundervisningen $\mathrm{i}$ årenes $1 \varnothing \mathrm{b}$, skyldes det især to ting. For det første anså tilhængerne af svensk gymnastik trods alt ikke redskabs$\emptyset$ velser for lige så vigtige som gruppeøvelser, hvor man bedst kunne sikre og kontrollere gymnastikkens virkning. Men - for det andet - især i landsbyernes skoler, var der slet ikke redskaber nok, hvilket i sig selv naturligvis tilgodeså stillingsgymnastik frem for redskabsgymnastik. ${ }^{16}$

\section{Gymnastik eller sport?}

I de nordiske lande har gymnastikken og delvist skyttebevægelsen fået en speciel placering i idrætshistorien som noget særligt fællesnordisk. Fælles nordiske gym- 
nastikstævner blev afholdt helt tilbage i 1880-erne, ${ }^{17}$ og gymnastikken blev af sine tilhængere anset for ædlere og renere end sport. I modsætning til sporten hævdede gymnastikkens tilhængere, at den tjente en højere sags tjeneste såsom fædreland og folkeopdragelse. ${ }^{18}$ Gymnastik var bedre til at opdrage ungdommen i den rigtige retning end sport, hævdedes det.

Gymnastikkens og skyttebevægelsens forhold til sporten var dog ikke kun et nordisk tema omkring århundredskiftet. Også i det фvrige Europa anså visse skytter og gymnaster deres aktiviteter for at have større etisk værdi end sport. Da stifteren af de moderne olympiske lege Pierre de Coubertin således i 1895 forsøgte at inddrage den franske skyttebevægelse i den olympiske bevægelse, fik han at vide, at det var utroligt, at han kunne forestille sig, at skydning skulle kunne tænke sig at blive »a mere branch incorporated and fitted into a whole series of sports $\ll .{ }^{19}$ Allerede inden kongressen i 1894, der førte til dannelsen af IOC havde præsidenten for det belgiske gymnastikforbund pure afvist at deltage. Hans forbund, skrev han til Coubertin, »had always belived and still believed that gymnastics and sports are two contrary things and has always fought against the letter «. ${ }^{20}$ Synspunktet var, at gymnastik især var orienteret mod en proces, der involverede opdragelse og holdning; sport var derimod især orienteret mod et produkt, der omfattende konkurrence og rekord. Også indledningen til det belgiske gymnastikforbunds egne vedtægter bekræfter, at det at være gymnast var noget særligt. Her hed det nemlig: »De Belgische turners zijn broeders «. ${ }^{21}$ Også udenfor Danmark og Sverige kendte man iøvrigt til »svensk « gymnastik. Den blev indført i f.eks. Belgien, England, Grækenland, Holland, Norge, Polen og Rumænien. ${ }^{22}$ Der- imod er det et specielt dansk fænomen, at den svenske gymnastik fik så stor betydning udenfor skole og hær, især i de frivillige gymnastikforeninger. I de andre lande blev den svenske gymnastik først og fremmest indført i skole eller hær.

Andre emner end fædreland og folkeopdragelse kunne imidlertid inddrages når sportstilhængere diskuterede med gymnastiktilhængere. »Men hvor er Lysten og Munterheden? « spurgte løjtnant Hougaard allerede i $1888 .{ }^{23}$ Spørgsmålet var rettet til gymnastikken og ikke til den sport, som Hovgaard propaganderede ivrigt for. Dermed var taget hul på et tema, der kan følges helt op i vore dage. Det kunne godt være, ironiserede sportstilhængerne, at gymnastikfolkene vidste, hvor musklerne sad og virkede, og at de troede at kunne bedømme gymnastikkens virkning på såvel legeme som ånd, men sjovt var det i hvert fald ikke. Andre tilhængere af sport gik endnu videre i deres kritik af gymnastikkens påståede virkninger, men set over hele perioden var det langt fra kun konflikt, som prægede forholdet mellem sport og gymnastik. I Danmark var der ved flere lejligheder samarbejde på topniveau mellem Dansk Idræts-Forbund (DIF) og De Danske Skytteforeninger (DDS) allerede omkring århundredskiftet. Og selv om sporten især havde tilknytning til byerne, så må gamle teser om, at der stort set ikke blev dyrket sport på landet, men kun gymnastik langt op i dette århundrede, forlades. Der blev dyrket sport både i foreningerne på landet, på mange højskoler og $\mathrm{i}$ en del landsbyskoler. ${ }^{24}$

Lægen Abraham Clod-Hansen, topleder i Dansk Gymnastik-Forbund så gymnastikken som noget grundlæggende for leg og boldspil: »Gymnastikken forholder sig til Legen som Gramatikken til Conversationen $\ll .{ }^{25}$ At betragte gymnastikken som et 
fundament var heller ikke ukendt i sportens verden. Så sent som i 1946 påpegede daværende formand for DIF, Herbert Sander i et tilbageblik »at det svenske mere fysiologisk velbegrundede systems indførelse havde været berettiget $\ll .{ }^{26}$ Sander så således især den svenske gymnastiks berettigelse som et fysisk grundlag for sporten. Dette synspunkt havde DIF tidligt. Det fremgår også af den begrundelse DIF i 1921 gav for at tildele Niels Bukh en fremtrædende rolle ved afviklingen af forbundets første instruktørkursus. Det skete nemlig »i Erkendelse af den store Betydning, den Bukhske primitive Gymnastik vil faa som Led i Idrætsmændenes Træning «. ${ }^{27}$ Man kan samlet sige, at der allerede både før og efter århundredskiftet var såvel en international som en nordisk og dansk tradition for kontrovers mellem tilhængere af gymnastik og sport, men også at spørgsmålet må nuanceres, og selvom gymnastikken alt $\mathrm{i}$ alt endte med at få en dominerende rolle i den danske skole, blev sporten ikke kørt helt ud på et sidespor. Men noget »strammet op« blev der trods alt:

Allerede inden »Kommissionen « i 1899 udsendte den færdige »Haandbog «, barslede den i 1897 med et delresultat, der blev udsendt under titlen »Lege, Boldspil og anden Idræt «. Delresultatet blev underst $\varnothing t t e t$ fra officielt hold. Allerede året før, i 1896, havde ministeriet udsendt et cirkulære, som stærkt anbefalede »ordnede Lege og Boldspil « i skolen. ${ }^{28}$ Af indholdet fremgik det, at boldspil var »en Sag, paa hvilken der fra Skolens og Hjemmets Side bør lægges den største Vægt«. Endvidere kunne læses, at »disse Lege ved den kraftige Bevægelse, hvori de sætte Legemet uden ensidigt at lægge Beslag paa enkelte Dele af dette, er en saa naturlig og heldigt virkende Form for Legems $\emptyset$ velser, at de i saa henseende, drevne paa rette Maade, staa over en hvilkensomhelst anden sportsmæssig Idræt (Roning, Ridning, Cykling o.s.v.) og fuldt ved Siden af den mest rationelt udviklede Gymnastik «. ${ }^{29}$

I maj 1900 landede et nyt cirkulære om samme emne imidlertid på bordet hos seminariernes rektorer. Der stod at læse, at bestemmelsen i juni 1897-cirkulæret om

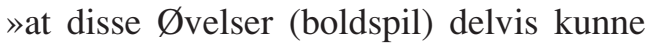
træde i stedet for Gymnastik, vil være at begrænse derhen, at der af de for Seminarierne normerede 4 ugentlige Gymnastiktimer kan anvendes een højst to Timer til disse Øvelser«. Færdigheder i lege og boldspil burde især »erhverves ved frivillig Beskæftigelse hermed uden for Undervisningstiden $\ll .{ }^{30}$ Eftertiden har set det første cirkulære fra 1897 som en styrkelse af den sportslige linje i skolen og det andet cirkulære fra 1900 som »svenskernes« modspil. Man kan dog også vælge at se 1900-cirkulæret som en justering af boldspillets placering i undervisningen, nu hvor Haandbogen var blevet helt færdig, og den moderne gymnastik skulle indplaceres. Og i den sammenhæng fik gymnastikken tildelt en mere fremtrædende rolle i skolefaget end leg og boldspil. Men deri var hverken den danske eller svenske fløj i skolegymnastikken uenig. Gymnastik - svensk eller dansk - var trods alt vigtigere end boldspil, og hvis man ikke passede på, kunne boldspil og leg tage overhånd. Det var en fare skolegymnastikken altid lå under for, og som man måtte være opmærksom på. ${ }^{31}$

Sporten var allerede kort efter århundredskiftet blevet den førende organiserede fritidsaktivitet i bymiljøerne herhjemme, men i skolen blev den som antydet holdt $\mathrm{i}$ stramme tøjler og underordnet gymnastikken. Det gav sig bl.a. udtryk ved skolereformen i 1899, hvor sporten blev tildelt en plads under samlebegrebet »anvendt gym- 
nastik «, der bestod af boldspil, »andre ordnede lege« og svømning. Overfor den anvendte gymnastik stod den »egentlige gymnastik «, som af »svenskerne« blev anset for at være den seriøse og virkningsfulde del af skolegymnastikken. Omvendt anså de den anvendte gymnastik for at være specielt egnet til morskab. Forholdet mellem sport og gymnastik var således at ligne med forholdet mellem leg og arbejde. At gymnastiktilhængerne så sporten som noget »alternativt« kan også ses af de pædagogiske anbefalinger om sport og leg. Læreren skal påtage sig dommerens rolle, træffe afgørelser og $\varnothing$ ve kritik, hed det i $»$ Haandbogen«, der yderligere slog fast: »Og endelig maa det være hans Opgave bestandig at gøre sig selv mere og mere overflødig, saa at det til sidst kan gaa ganske uden hans Lærermedvirkning «. ${ }^{32}$

En tilbageholdende, for ikke at sige usynlig lærer, ville aldrig være blevet anbefalet eller accepteret $i$ forbindelse med den »egentlige gymnastik«. Det må dog ikke foranledige til at tro, at begrundelsen var, at sporten blev anset for at være så ligegyldig, at læreren ikke behøvede at være til stede. Snarere skal anbefalingen om tilbageholdenhed ses på baggrund af de kvaliteter, leg og sport blev tillagt. Legen og sporten var, hvad den »sjælelige Opdragelse « angik af stor betydning: »Enhver Leg er som et forkortet Billede af selve Livet. En mængde af de Egenskaber, vi regne for særlig værdifulde i Livet: Ansvar, Hjælpsomhed, Hensynsfuldhed, redebon Indordning under det større Hele o.s.v.«. Og set i den sammenhæng kan der ikke »blive Tale om en forud tilrettelagt Kommando. Eleven maa nu i ethvert Øjeblik selv iagttage Situationen og derefter selv indrette sin Handlen « ${ }^{33}$

Stod det til eleverne selv, var der ingen tvivl om, at den egentlige gymnastik »i sig selv er af ringe Interesse for Eleven ${ }^{34}$ »Haandbogen « fra 1899 - må det understreges - var, udover at den var udtryk for kompromis mellem tilhængere af »dansk « og »svensk « gymnastik, også et kompromis mellem gymnastik i forhold til leg og sport. Derfor var bogen nok mere venlig overfor legen og sporten, end mangt en gymnastiktilhænger syntes om. Der var dog ingen tvivl om, at den egentlige gymnastik var den vigtigste aktivitet, og at det var her, læreren skulle gøre sin indsats:

»Efter hans (lærerens) Ordre udføres enhver af Bevægelserne. Der kommer et vist mekanisk, fast Præg over det hele. Men dette bevirker til Gengæld, at der her kan holdes nøje Overblik over, hvad der er gjort og hvad der endnu bør gøres. Hver enkelt Muskel kan, om man saa maa sige, her faa nøjagtigt, hvad der tilkommer den, ligesom man her kan passe paa, at den enkelte Bevægelse føres ud til den yderste Grænse af Bevægelsesbanen, hvorved netop den rette Holdning og Udformning af Legemet vindes. $\ll^{35}$

Den efterstræbelsesværdige rette holdning kunne man aldrig opnå gennem leg og sport. For at opnå den krævedes gymnastik.

Gymnastik efter »svenske principper « havde sin storhedstid i perioden fra århundredskiftet frem til 1. verdenskrig. Fra 1912 begyndte bevægelsesgymnastikken at blive dominerende på landet. Den rettede i Niels Bukhs udgave, den primitive gymnastik, især sin opmærksomhed mod tre kropsøvelser, som blev varieret i det uendelige: bøjning fremad og bagud, bøjning til siderne og kropsvridning. Makkeren erstattede de bomme og ribber, der blev brugt i den svenske gymnastik. ${ }^{36}$ Bukhs gymnastik lagde i sin oprindelige udform- 
ning stor vægt på disciplin, kommando og formgivende $\emptyset$ velser. Bukh havde naturligvis sin hovedbastion i højskolen, men fik $\mathrm{i}$ løbet af 1920-erne stor indflydelse i skolegymnastikken, hvor hans gymnastik blev positivt modtaget af K.A. Knudsen. Bukhs gymnastik tilføjede først og fremmest en række nye øvelser samt bevægelse til den svenske gymnastik. Den var ikke et nyt system, men en ny gymnastisk arbejdsmåde. Også den finsk-svenske gymnastikpædagog Elli Björksten øvede sin indflydelse i denne udvikling.

Den interesse for sport og leg, der havde været omkring århundredskiftet, blev ikke mindre. Foregangsmand var Frederik Knudsen, der var ansat som boldspilslærer på »Gymnastikkurset« og »Gymnastikinstituttet « i perioden 1898-1930. Hans base var udover arbejdspladsen i København også »Udvalget for danske Skolebørns Fælleslege«, dannet i 1896. Udvalget arrangerede en række sommerkurser $\mathrm{i} \gg$ ordnede lege og boldspil« for skolelærere og stod bag udgivelsen af mange publikationer om emnet. ${ }^{37}$ Der herskede udpræget »fredelig sameksistens « mellem udvalget for skolebørns fælleslege og den svenske gymnastik, personificeret ved henholdsvis Frederik Knudsen og hans chef K.A. Knudsen. Når der ikke opstod konflikt skyldes det muligvis, at legetilhængerne, der ofte selv var lærere ikke angreb den svenske gymnastiks førerposition. ${ }^{38}$

Det skolefolk ofte var modstandere af, i forbindelse med sport, var nok så meget den betydning sporten blev tillagt i offentligheden, og den måde den blev organiseret på i klub og forening, som det var sporten i sig selv. Det var især sportens konkurrencemoment, man var modstander af. Men omvendt blev netop sportens konkurrencemoment også et argument for at få den ind i og beholde den i skolen. Kun der kunne man nemlig forholde sig pædagogisk til den. Netop kampen for at holde organiseret sport væk fra skolen, demonstrerer dette. I 1920 argumenterede et udvalg for, at man herhjemme ikke burde gøre, som man havde gjort i Sverige og organisere den skolesport, eleverne var begyndt at gøre frivilligt i skolen efter skoletid, i en særlig organisation. Det skete først i Danmark i 1947 med dannelsen af Landsudvalget for Skoleidræt. Begrundelsen i 1920 var, at skolen selv skulle bevare kontrollen: »For det forste, fordi det giver den bedste Borgen for, at Idratten fores frem ad de rette Baner med udelukkelse af ensidighed og overdrivelse og $i$ Samklang med Skolens фvrige Arbejde. For det andet, fordi Idratten er et betydningsfuldt Middel for Lareren til at fä foling med Eleverne og til at virke opdragende og karakterdannende på dem, et Middel, det vil vare uklogt, ja til stor Skade for Skolen, at lade sig glide af Hande «. ${ }^{39}$ Argumentationen er således, at sporten er skadelig udenfor skolen, men et godt pædagogisk middel indenfor.

Sportens konkurrencemoment var en kilde til evig bekymring for skolefolk. Københavns gymnastikinspektør udtrykte det præcist i 1926 i en tale i Pædagogisk Selskab: »Idrætsbevægelsen er gået langt ud over Grænserne for det rimelige, og er nået et godt stykke ind på det latterliges Område. Man måler de opnåede Resultater i Brøkdele af Sekunder og Meter.« Han fandt det rimeligt, »at man havde Laurbærkrandsen parat til dem, der har kæmpet bravt, men jeg vil have, at den skal være udtryk for festlig Glæde, og mindre end det nu er tilfældet, skal minde om en Skalp, der flås af en besejret Fjende«. »Idrætsbevægelsen er imidlertid endnu inde på Afveje, som må gøre det betænkeligt for Skolen at indlade sig på et Samarbejde $\ll{ }^{40}$ Desuden fandt inspektøren, at sporten ikke nær 
nok søgte tilknytning til »åndelige Værdier«. Det var dog ikke muligt at holde den sportslige konkurrence ude af skolen. Skoler havde konkurreret mod hinanden gennem mange år. Allerede fra 1898 havde gymnasieskolerne med mellemrum afholdt store gymnastik- og idrætsstævner. ${ }^{41}$ Traditionel »dansk « gymnastik var fra start den dominerende disciplin i gymnastikstævnerne, men snart kom atletik og boldspil med. Stævnerne blev afbrudt af første verdenskrig, men dernæst gennemført hvert 34 år. Fra 1935 holdt også realskolerne årlige stævner. ${ }^{42}$ I løbet af 1920-erne forekom der også konkurrencer mellem folkeskoler mange steder i landet f.eks. i de større købstæder. I Århus var der således årlige fodbold- og håndboldturneringer for byens skoler, og i København afholdtes 1930 idrætsdag for samtlige skoler. Fra 700-800 deltagere steg deltagerantallet til det 10 dobbelte i løbet af de følgende år. ${ }^{43}$ Denne stævneaktivitet var naturligvis en afspejling af, at sporten fik en styrket placering i skolen, som den allerede havde det i samfundet. Den havde aldrig været holdt ude, det viser de årlige indberetninger fra skolemyndigheder og gymnastikinspektører, men efterhånden fik den en mere dominerende plads, end den var tiltænkt.

Et udtryk for dobbeltheden i skolens forhold til sport - at idrætskonkurrence var forkasteligt, men at hvis det skulle være, så måtte man i det mindste holde den indenfor skolens rammer - kan ses i holdningen til skoleidrætsmærket. Efter en del diskussioner, og efter at det almindelige idrætsmærke var blevet indført året før, vedtog man at indføre skoleidrætsmærket i 1922. Formålet med mærket var »at vække og vedligeholde Interessen hos Skoleungdommen for Sund og mådeholden Idræt «. ${ }^{44}$ Idrætsmærker er naturligvis også udtryk for konkurrence, men det er først og frem- mest i forhold til sig selv, man konkurrerer, og det gjorde det mere spiseligt for gymnastiktilhængerne. Det idrætsmærke, man valgte, var kompliceret at tage, kompliceret at få og kompliceret at bære. For overhovedet at måtte tage det, skulle man have mindst mg i karakter i gymnastik. Indholdet var i sig selv kompliceret med mange typer af aktiviteter. At få mærket krævede, at et større kontrolbureaukrati blev aktiveret, og der var strikse regler for dets brug og placering på tøjet. Det kan derfor ikke undre, at der de første år kun blev taget nogle få hundrede hvert år. ${ }^{45}$

Den aktive rolle, administrationen i København spillede i forbindelse med indførelsen og placeringen af gymnastikken i det danske skolesystem, kunne også efterfølgende ses i forsøget på at sikre en ensartet undervisning. Til det brug havde man først og fremmest »Timesedlen « også kaldet $\gg$ Dagsøvelsen «, der - ofte minutiøst fastlagde indholdet $\mathrm{i}$ den enkelte gymnastiktime. ${ }^{46} \gg$ Timesedler « var et væsentligt styresystem for skolegymnastikken. De kan nemlig udarbejdes centralt og krav til opbygningen kan sikre, at de rigtige $\emptyset$ velser bruges i rette sammenhæng og rækkefølge. Den første bog med timesedler efter svenske principper var forfattet af K.A. Knudsen selv. I årenes løb blev kravene til deres opbygning og indhold ofte indskærpet, og nye samlinger blev udgivet. De første timesedler var beregnet for mandlige elever, men de kvindelige fik hurtigt deres egne. ${ }^{47}$ Den svenske gymnastik skelner ikke i princippet mellem $\emptyset v e l s e r$ for mænd og kvinder, men i sine timeøvelser for kvindelige elever havde Knudsen taget de dele af Håndbogens $\varnothing$ velsesstof, som han fandt særligt egnet til piger. Også på anden vis søgte man at styrke skolegymnastikken. I 1903 blev det bestemt, at gymnastikken skulle have bedre 
skematimer end tidligere, hvor den var placeret som sidste time. I 1904 blev det besluttet, at staten kunne yde tilskud til opførelse af gymnastikhuse og til efteruddannelseskurser, og i 1907 blev det fastlagt, at byggetilskud kunne ydes på op til halvdelen af, hvad en gymnastiksal kostede. ${ }^{48}$

Inspektion, kontrol og vejledning, var områder, der blev satset særligt på. Hvor gymnastikinspektionen ved århundredskiftet kun havde bestået af en fast inspektør, blev der hurtigt ansat yderligere 2 gymnastikinspektører, samt i de følgende år yderligere $15 » l \varnothing s e$ heraf tre kvinder. Gymnastikinspektørerne skulle både sikre, at skoleidrætten blev udført på forsvarlig faglig måde, og at faciliteterne var i orden. Med de nye inspektørers ansættelse kunne det sikres, at skolerne fik bes $\emptyset \mathrm{g}$ ca. hvert femte år, istedet for hvert 20! Yderligere udviklede man den praksis, at hver gang en skole blev besøgt, blev gymnastiklærerne fra de 2-3 nærmeste skoler også inviteret. Bortset fra at en del lærere ikke efterkom invitationen, kunne man i teorien komme $\mathrm{i}$ direkte kontakt med alle gymnastiklærere i løbet af en toårig periode. ${ }^{49}$

Inspektørerne så det selv som deres væsentligste opgave at hjælpe og vejlede. Lærerne fra naboskolerne var som nævnt også inviteret til besøget og ofte også medlemmer af sognerådet. Dagens program kunne starte med, at den stedlige lærer viste gymnastik med sine elever. Inspektøren kunne herunder bryde ind med rettelser. Dernæst overtog inspektøren selv klassen og fik gjort den interesseret »saa de Øvelser, han kommanderede, gik med adskilligt mere Liv end under dagligdags Forhold «, som bladet $»$ Skole og Samfund « berettede fra en inspektion. ${ }^{50}$ Efter dette indslag kunne inspektøren f.eks. demonstrere et program i skolestuegymnastik. Til sidst var der mulighed for diskussion og spørgs- mål, samt eventuelt et foredrag om gymnastikkens betydning for legemligt og åndeligt velbefindende. Men det kan ikke nægtes, at det kunne være hårdt for den enkelte lærer at få udstillet sine eventuelle faglige og pædagogiske mangler overfor egne elever, kolleger fra naboskolerne og medlemmer af kommunalbestyrelsen. En inspektør skrev efter et bes $\varnothing \mathrm{g}$ : »Der sidder indgroet i Sindet hos de allerfleste Lærere en nedarvet Uvillie mod al Inspektion, og saa længe denne Uvillie er raadende, kan der intet godt udrettes gennem Tilsynet $\aleph^{51}$

\section{Selvforståelse og virkelighed}

De indberetninger, som inspektørerne gav, viste, at der ofte var langt mellem den centrale selvforståelse og den lokale virkelighed..$^{52}$ Det var et slid at få den moderne skolegymnastik installeret. Problemer var der mange af især i periodens begyndelse, både hvad faciliteter, lærerkvalifikationer, elevinteresse og lokal opbakning angik.

Ved århundredskiftet var gymnastikundervisningen ved en række skoler noget der $\gg$ tit kun fandtes paa Papiret eller var en sørgelig Parodi $\kappa^{53}$ Efter ca. 10 år under reformen var der lyspunkter, men problemerne var store. Hvad faciliteter angik, demonstrerer indberetningerne udbredt manglende vilje eller evne til at sikre nødvendige, for slet ikke at tale om lovpligtige, forhold for skolegymnastikken ude på landet. Her tænkes ikke på det ekstreme tilfælde, hvor en lærer selv havde bygget gymnastiksal for egen regning, men de mange tilfælde af almindelig dårlig vilje. Den var der mange steder, men skal man tro en indberetning fra 1907 var specielt Thisted amt et sted, hvor skolegymnastikken var i særlig lav kurs. I hvert fald sammenlignet med Holbæk amt som den pågældende gymnastikinspektør også havde 
under sig. Særlig slemt stod det åbenbart til i Thy. Generelt for området skrev inspektøren advarende: »Hvis Befolkningen ser paa Gymnastikundervisningen som noget overflødigt og unyttigt, og som noget, der stjoeler af den Tid, der kunde anvendes til Arbejde for Forceldre eller Husbonde, saa hammes Gymnastikken og Larerens Interesse svakkes. Ofte ses der ogsaa skavt til enhver ny Anskaffelse af Redskaber, fordi den er forbunden med Udgifter. " ${ }^{54}$

Inspektøren var dog ikke blind for, at det ikke kun var et spørgsmål om manglende vilje, men også manglende muligheder. Thisted amt var fattigt sammenlignet med Holbæk, og det havde også indflydelse på skolegymnastikkens muligheder. I mange skoler i Thisted amt, gik de ældste klasser kun i skole een gang om ugen i sommerperioden, eller havde helt fri i 2-3 måneder af skoletiden. Når han inspicerede i Jylland, så han sjældent børn lege, hævdede han. Årsagerne dertil skulle muligvis søges i en roligere jysk folkekarakter, men inspektøren mente dog, det snarere skyldtes, at børnene var trætte. De arbejdede fra solopgang til solnedgang og mange børn på 1012 år var »stive i Bryst og Skulder saavel som i andre Led og rundryggede «. Yderligere havde mange allerede »et vist gammelmandsagtigt forslæbt Præg «. Om sommeren lod nogle lærere dem simpelt hen sove et par timer om dagen, når de kom i skole. ${ }^{55}$ I vinteren 1906-07 undersøgte en skolelæge i Jylland over 1000 børn i Midtjylland. Hos en fjerdedel af husmandsbørnene og en femtedel af gårdmandsbørnene fandt han, at her var: »Hovedet sænket, $\emptyset$ verste del af Ryggen rundet, Skulderbladende hængende, Brystet indfaldent, Maven fremskudt, Hofteled og Knæled bøjede fremad, Tæerne indad «. Det var, påpegede lægen, den typiske arbejdsstilling hos landalmuen, det var den stilling de gamle slidere stivnede i i 50-års alderen, men den kunne ses hos børn helt ned i 7 års alderen. ${ }^{56}$ Omkring 1900 var ca. $40 \%$ af befolkningen beskæftiget indenfor landbruget. I 1922 blev det forbudt børn under 14 år at arbejde i håndværks- industri- og transportvirksomhed. I landbruget var børnearbejde stadigvæk nødvendigt, så der blev grænsen sat ved 10 år.

Uviljen mod at bruge penge på skolegymnastikken kendetegnede mange indberetninger ikke kun fra Nordjylland. Mange skolekommissioner og sognerådsformænd indberettede således år efter år, at alt var i orden, selv om der f.eks. ingen gymnastikredskaber var købt. Mange steder klagede lærerne til sidst til ministeriet og autoriteter. I nogle tilfælde blev der købt redskaber, men ikke sørget for steder at opbevare dem. De stod så ude i al slags vejr og rådnede op i løbet af få år, på de åbne gymnastikpladser der ofte var helt åbne for vind og flyvesand og i virkeligheden umulige at undervise ordentlig på i store dele af året. Alt i alt var der mange steder i landet, hvor der efter ti år med den nye ordning, slet ingen forståelse var for skolegymnastikkens gavnlighed. Mange lærere var utrygge ved de nye krav. Nogle så meget at de betalte sig fra det. Der er flere eksempler på, at lærere betalte stedlige gymnastikinstruktører fra De Danske Skytteforeninger af egen lomme for at undervise i gymnastik, andre steder overtog gymnastikinstruktørerne undervisningen uden betaling. Denne praksis var gymnastikinspektørerne naturligvis bekymrede over. Dels kunne man ikke forudsætte, at en delingsfører havde en børnepædagogisk uddannelse og derfor måske kunne finde på at lave voksengymnastik med børnene, dels kunne en sådan ordning medføre, at gymnastik fik en underordnet placering i skolen. ${ }^{57}$ Et af de forhold, der heller ikke 
hjalp på lærernes entusiasme og humør, var, at skolegymnastikken næsten altid betød ubetalt ekstraarbejde, idet den blev lagt oven i undervisningsbyrden. Den var obligatorisk - for drenge - i det mindste i teorien. Den lærer, der underviste i gymnastik, havde således mange steder længere arbejdsuge end kollegaerne.

Hvad der imidlertid heller ikke virkede befordrende for entusiasmen, var den kendsgerning, at mange lærere slet ikke kunne se nødvendigheden af faget. »Jeg vil hellere tage mod en Røffel af mine Overordnede, end jeg vil staa her paa denne elendige aabne Plads og gøre baade mig selv og Børnene til Grin for Vejfarende Folk $\aleph^{58}$ sagde en lærer således, da han i begyndelsen af århundrede blev spurgt, om han lavede gymnastik med sine elever. En anden udtalelse - oven i købet fra en kendt skolemand, der nok burde vide bedre påpegede ca. 25 år efter at »Gymnastik er fortræffeligt, men Husgerning er dog vigtigere «. Der var med andre ord mange slags vanskeligheder at overvinde og den kendsgerning kan passende (igen) minde om, at læseplaner, lovgivning og formulerede formål kan hjælpe til at forstå indholdet i en officiel ideologi, til at forstå et systems selvforståelse. Men den slags kilder har ikke nødvendigvis noget med virkeligheden at gøre. Et er nemlig, hvad der besluttes centralt, noget ganske andet er, hvad der rent faktisk foretages lokalt.

Omkring 1930 - efter en generations arbejde for gymnastikkens udbredelse i den danske skole - var resultatet ikke helt opløftende og slet ikke på landet. På det tidspunkt var der ca. 240 byskoler med ca. 170.000 elever og ca. 3600 landskoler med omkring 270.000 elever: ${ }^{59}$

* 2/3 af skolerne på landet havde ingen gymnastiksal. Næsten alle byskoler havde dog adgang til sal.
* $1 / 4$ af pigerne på landet blev ikke undervist i gymnastik. I byerne havde alle piger modtaget undervisning siden ca. 1920.

* 1/2 af eleverne på landet modtog kun skolestuegymnastik.

* $1 / 3$ af lærerne på landet var ikke uddannet i gymnastik efter de svenske principper. I byerne var kun 1/20 af lærerne ikke uddannede.

* 3/4 af skolerne på landet havde ikke bademulighed, og det havde $1 / 4$ af skolerne i byerne heller ikke.

* 1/40 af eleverne på landet blev undervist i svømning. Det var uændret i forhold til 25 år tidligere!

* 2/3 af eleverne i byerne blev undervist i svømning, hvilket var en $10 \%$ stigning i forhold til 25 år tidligere.

* 2/3 af eleverne på landet blev ikke undervist i boldspil og leg, i byerne blev $1 / 20$ ikke undervist i disse aktiviteter.

Det ses således, at der stadig i 1930 var mange piger, der ikke blev undervist $\mathrm{i}$ gymnastik. Hvad specielt pigernes deltagelse i skolegymnastik angår, er det en ofte gentaget myte i dansk idrætshistorie, at skolegymnastik for piger blev genindført med skoleloven af $1904 .{ }^{60}$ Som det er fremgået af ovenstående fik dog langt fra alle piger gymnastik i 1904, og det står da heller ikke i skoleloven samme år. Her fremgår det nemlig, at piger kun skal undervises i gymnastik i byskolerne, hvis fornødne lærerkræfter haves, og i skolerne på landet kun hvis sognerådet synes. ${ }^{61}$ Først med skoleloven i 1937 kom der et krav om, at begge $k \emptyset n$ skulle undervises gennem hele skolesystemet i idræt. ${ }^{62}$

Som det også fremgår af oversigten, lagde ikke mindst badefaciliteterne meget tilbage at $\emptyset$ nske. Men paradoksalt nok blev eksisterende bademuligheder heller ikke 
altid udnyttet $\mathrm{i}$ forbindelse med gymnastiktimerne. Bruserne blev ofte især brugt til at sikre, at eleverne fik et renselsesbad hver 14. dag. Det skemalagte regelmæssige renselsesbad skønnedes - der hvor det var indført - åbenbart at være mere effektivt i en hygiejnesammenhæng end den mere tilfældige badning efter skolegymnastikken. Eller måske ønskede man simpelt hen ikke at frådse med det varme vand. Københavns gymnastikinspektør $\varnothing n-$ skede i et foredrag i 1934, at det renselsesbad, som mange skoler havde indført, skulle erstattes af fast badning efter skoleidrætten. Dog ikke kun for renlighedens skyld, men også for opdragelsens. »Har Befolkningen først gennem Skolen faaet bibragt den Vane regelmæssigt at tage Bad, skal den nok vedblive dermed $\ll .{ }^{63}$ I mange skoler var der renselsesbade til ca. 1960.

I byerne var forholdene generelt bedre for skolegymnastikken end på landet, hvad faciliteter angik. Men på grund af tilstrømningen fra land til by var forholdene heller ikke her altid optimale. I København, der egentlig var kendt som foregangskommune på skolegymnastikkens område, var forholdene i nogle skoler i perioden op mod 1. verdenskrig nærmest absurde. De gode intentioner Københavns kommune allerede før århundredskiftet havde haft om at levere gymnastik til alle aldersklasser og begge $k ø n$, blev $\varnothing$ delagt af tilstrømningen til byen og udvidelsen af kommunen. Der var eksempler på, at 70 elever blev undervist på én gang i gymnastiksalen, og i ekstreme tilfælde spændte elevgruppens alderssammensætning fra 7 år til 14 år. København gav i $190375 \%$ af folkeskolens piger undervisning i gymnastik, men i 1913 kun $70 \%$. Altså en nedgang stik modsat landstendensen og byens egne principielle beslutninger. ${ }^{64}$

Generelt var faciliteterne bedre i gymna- sieskolerne end i de andre skoler, men også der havde skolegymnastikken sine problemer. Undervisningen var ofte præget af tidligere tiders militært uddannede lærere, der ikke altid var overbeviste om de svenske princippers velsignelser, og også elevernes fritagelse kunne være et problem. I 1919 blev det besluttet, at der skulle gives medtællende årskarakterer i gymnastik ved studentereksamen på samme måde, som det siden 1907 havde været tilfældet ved realeksamen og fra 1908 ved mellemskoleeksamen. Der var en vis frygt for, at det ville $\emptyset$ ge det i forvejen store frafald ved lægeerklæringer, men karaktererne kom til at virke modsat. For drengenes vedkommende faldt frafaldsprocenterne fra ca. $22 \%$ før loven til $15 \%$ efter. De samme tal var for pigernes vedkommende henholdsvis $49 \%$ og 29\%. Frafaldet blev således markant mindre, selv om det dog ikke nåede ned på »realklasseniveau «, hvor fritagelsesprocenten var på ca. $9 \%$ for drenge og ca. $15 \%$ for piger. Det gennemsnitlige procentfald dækkede dog over store udsving, der kun kan forklares ved tradition og lokal kultur. Også efter karakterernes indførelse kunne man nemlig finde - omend få - gymnasier med regelmæssige fritagelsesprocenter på op mod 70 for drengenes vedkommende og 100 for pigernes. ${ }^{65}$

\section{Gymnastikkens virkninger}

Fra første verdenskrig blev den svenske gymnastik som nævnt ændret, bl.a. blev tempoet $\varnothing$ get og mere bevægelse tilføjet. Den svenske gymnastiks overordnede påstand om gymnastikkens særlige virkninger blev i stigende grad angrebet. »Den rette ryg « som udtryk for »den rigtige holdning « kom til at stå centralt i debatten.

I eftertiden er denne strid blevet personificeret som en strid mellem den ivrige for- 
kæmper for svensk gymnastik, cand.theol. K.A. Knudsen, der 1898-1927 var leder af den praksisorienterede del af idrætsuddannelsen, og naturvidenskabsmanden, dr.med. Johannes Lindhard, der 1912-1938 stod i spidsen for den teoribaserede universitetsuddannelse i idræt. De var da også de mest fremtrædende, men langt fra de eneste deltagere i debatten. Lindhard og Knudsen repræsenterede snarere hvert sit bagland. Striden, der kulminerede i slutningen af 1920-erne, var også et opgør mellem akademikere og videnskabelige autoriteter på den ene side og pragmatiske lægfolk og praktikere på den anden side. Lindhard repræsenterede således en »ny« type videnskab, der ikke stillede sig tilfreds med, som ved århundredskiftet, at argumentere »videnskabeligt « ved hjælp af erfaringer, idealistisk tro og analogier. Der skulle facts på bordet!

Diskussionen mellem Knudsen og Lindhard var ikke - må det fastslås - for og imod svensk gymnastik, som de begge var tilhængere af. Spørgsmålet var, om den svenske gymnastik - eller for den sags skyld en hvilken som helst form for idræt hvilede på videnskabelig grund. Var det f.eks. videnskabeligt bevist, at den svenske gymnastik havde virkning på sundheden eller ej? Og i den sammenhæng: var den rigtige holdning, udtrykt gennem den rette ryg, en indikator for fysisk og mental sundhed? Det kom f.eks. til udtryk i 1917 efter at Lindhard havde overværet en Bukh-opvisning i København: »Det kan være godt nok, at man ved Hjælp af formgivende $\emptyset$ velser er i stand til at smidiggøre Legemet; men det næste og vigtigste Spørgsmål bliver, hvad man derefter skal bruge Smidigheden til; den hører jo dog ikke med til de absolutte Livsværdier. $«{ }^{66}$ Det var et kernepunkt for tilhængere af den svenske gymnastik, at den var videnskabeligt fun- deret. $\mathrm{Og}$ det var ikke mindst for at få det yderligere bekræftet, at Knudsen og den svenske fløj tidligt pressede på for at få knyttet gymnastikuddannelsen til universitetet. Tilhængerne af den svenske gymnastik ønskede nemlig yderligere videnskabeligt bevis for dens pædagogiske og især sundhedsfremmende effekt. Knudsen hilste derfor Lindhards ansættelse på det naturvidenskabelige fakultet velkommen i $1912 .^{67}$

Lindhards kritik var en sundhedskritik og kan generelt opdeles i tre hovedpunkter, nemlig 1) en generel kritik af dogmet om gymnastikkens og idrættens sundhedsbringende effekt, 2) en kritik af den »gode holdning « som indikator for sundhed, og 3 ) en kritik af gymnastikkens manglende alders- og kønsdifferentiering. ${ }^{68}$ For Knudsen kunne holdningen tages som en ufejlbarlig indikator for sundheden, og den gode - og altså sunde holdning - blev i ord og billede tydeligt defineret. ${ }^{69}$ Ryggen skulle være ret - helt ret. Lindhard var ikke hvad der ofte påstås - fuldstændig afvisende overfor bestræbelserne på at korrigere kropsholdningen, heller ikke selvom hvirvelsøjlens krumninger formindskedes. De måtte blot ikke udslettes. Lindhard agiterede $\mathrm{i}$ stedet for en retstilling, der accepterede det menneskelige legeme således, som det nu en gang var skabt. ${ }^{70}$ For Lindhard var en god holdning en smuk holdning. For Knudsen var en god holdning en sund holdning. En god holdning gav sig især hævdede han - udtryk i en ret ryg, der således omvendt blev et udtryk for sundhed. Bestemte $\varnothing v e l s e r$ havde alle specifikke formål i retning af at skabe den gode holdning, hævdede Knudsen. Det er et paradoks, at selv om det er deres strid, eftertiden husker, var der i virkeligheden ikke den store afstand i deres synspunkter på, hvordan gymnastikken skulle udøves, 
og hvilken gymnastik der skulle udøves. Begge tog udgangspunkt $\mathrm{i}$ den svenske gymnastiks $\emptyset$ velsesforråd, som det var beskrevet i 1899-håndbogen, og begge så retstillingen og den formgivende gymnastik som centrale elementer. Men hvad gymnastikkens virkninger angik var de helt uenige.

For at bevise sin påstand om at gymnastikøvelser ikke havde specifikke virkninger på holdningen, foretog Lindhard bl.a. en stor serie målinger - med en såkaldt thoracograf - af ryggens og brystkassens form og bevægelighed, dels i stående stilling, dels i en række gymnastiske stillinger f.eks. strækstilling, spændbøjstående stilling, fremadbøjet stilling. Resultaterne af 19 unders $\emptyset$ gte gymnastiske $\varnothing$ velser, hvis formål angiveligt var at $\emptyset$ ge brystkassens bevægelighed og rumfang, viste, at kun en (stående kropsfælding fremad) kunne bruges til dette formål. Resten gav nemlig direkte nedsat bevægelighed og rumfang af brystkassen, sammenlignet med almindelig stående stilling. ${ }^{71}$

Håndbogens, Knudsens og Bukhs inddeling af $\varnothing$ velserne efter legemlig virkning og effekt afviste Lindhard altså. I stedet skulle man inddele i fire hovedgrupper:

1) Disciplinerende $\varnothing$ velser (ordnings$\emptyset$ velser, anstandsøvelser og gang$\emptyset$ velser).

2) Formgivende $\emptyset$ velser (systematisk bearbejdning af muskler og led).

3) Koordinations $\varnothing$ velser (ligevægts$\emptyset$ velser).

4) Kraft, udholdenhed og beslutsomhed (march, løb, spring og behændighedsøvelser).

Denne inddeling vandt hævd i gymnastiklitteraturen og -undervisningen fra midten af 1920-erne og flere årtier fremover. ${ }^{72}$
Idrættens værdi efter Lindhards mening var, at den var et nydelsesmiddel. Den havde værdi i sig selv. Fordelene bestod således nærmest i mentale sidegevinster. Man kunne blive i godt humør af idræt. Som nævnt tillagde også Knudsen idrætten mentale fordele. Men de mentale fordele, Lindhard tillagde idrætten, var ikke, som hos Knudsen, betinget af en bestemt aktivitet (den svenske gymnastik), en bestemt kropsholdning (den rette ryg) eller en bestemt udførelse (i alsidighed, i øvelsesrækkefølge, i taktfast samtidighed samt under disciplin og kommando). Det er blevet sagt, at for Lindhard var idræt at sammenligne med vin, mens den for Knudsen var at sammenligne med medicin. ${ }^{73}$ Lindhard udførte sine fors $\varnothing \mathrm{g}$ og fremførte i stærk polemisk form en kritik af den svenske gymnastiks påståede videnskabelighed. Den kunne ikke, hævdede Lindhard, søge sin legitimitet $\mathrm{i}$ anatomien og fysiologien, men skulle søge den i etikken og æstetikken. Ironien i Knudsens og Lindhards forskellige syn på gymnastikkens legitimitet er slående. Knudsen, der var teolog og praktiker søgte gymnastikkens grundlag i naturvidenskaben, mens Lindhard, der var naturvidenskabsmand søgte den i etikken og æstetikken. Altså søgte de hver for sig gymnastikkens legitimitet indenfor områder, de ikke var eksperter i. ${ }^{74}$

Som diskussionen mellem sportstilhængere og gymnastiktilhængere som tidligere nævnt ikke kun var en lokal dansk eller nordisk forteelse, men en international, var ideen om, at idrætten kunne tillægges særdeles væsentlige mentale og nationale fordele heller ikke kun dansk og nordisk. Begreber som »psykisk velbefindende «, »karakterdannende«, »moralsk udviklende«, »fædrelandskærlighed «, »internationalisme « og »demokrati« bruges igen og igen $\mathrm{i}$ den europæiske debat. Således også af 
Pierre de Coubertin og den olympiske bevægelse. ${ }^{75}$

I debatten herhjemme kunne man også finde mellemstandpunkter mellem Knudsens og Lindhards fløje. Mange havde det synspunkt, at idræt kunne bibringe sine udøvere større sundhed. De mente, at sundhedseffekten i højere grad skulle måles på den aktives almindelige velbefindende, veloplagthed, vigør og følelse af at organerne var velfungerende. Det var altså en konflikt mellem en sundhedsdefinition udfra en ren medicinsk, og et mere »livskvalitetsorienteret « synspunkt. Tilhængerne af sidstnævnte synspunkt pegede bl.a. på en række fysiologiske forhold, som udvikledes gennem legemsøvelser, og som de anså for sundt for det »moderne Menneske «. ${ }^{76}$ Lindhard fastholdt imidlertid, når han mødte den slags argumenter, som han kaldte $»$ ansvarsl $\varnothing s$ agitation $\ll,{ }^{77}$ at idrætsfolk ikke var bedre stillede m.h.t. sygdom og død end andre folk. Ganske vist kunne menneskets ydeevne og muskelstyrke $\varnothing$ ges gennem idræt, men dette gav ingen længere levetid og ingen profylaktisk virkning. Havde det været tilfældet, ville forsikringsselskaberne sikkert have lanceret reducerede præmier for idrætsfolk!

\section{»Et rent legeme giver rene tanker «}

Fra århundredskiftets start var sundhed et centralt tema i såvel den offentlige debat som litteraturen. En del af debatten førtes på en slags metaplan og havde allerede et par generationer på bagen, idet den udsprang af en socialdarwinistisk og nationalistisk tro på, at en nation kun var noget gennem sit folks kraft. En degenereret nation kunne ikke klare sig, idet den jo bestod af fysiske - og dermed også psykiske - svæklinge. ${ }^{78}$ I mellemkrigstiden gav denne overbevisning sig udtryk i en række racehygiejniske forstanstaltninger i hele Europa. En nation måtte sikre sin mentale renhed. Skolegymnastikken var velegnet til, hævdedes det, at sikre nationens fysiske og psykiske beredskab.

En anden del af sundhedsdebatten var mere jordnær og handlede om en anden form for hygiejne, den fysiske renhed. Også denne debat blev fulgt op af konkrete tiltag, hvor skoleidrætten var indblandet. Der var især tre strategier, der blev fulgt. Den første strategi var at holde kroppen helt ren. Hvis man ikke var ren, blev man syg - et rent legeme var et sundt legeme. ${ }^{79}$ Denne »husk-at-vaske-dig « strategi var tidligt i århundredet synlig i skolegymnastikken, men led naturligvis under den håbløse mangel på badefaciliteter. Den anden strategi var nærmest modsat. I stedet for at bekæmpe sygdom skulle man arbejde for sundhed. Legemet skulle hærdes til at modstå sygdomsangreb. Den tredie strategi, at oparbejde kunstig modstandskraft via vaccination, var ikke specielt interessant for skolegymnastikken. De tre strategier eksisterede samtidig. Skole, renlighed, krop og idræt indgik således som væsentlige elementer i periodens sundhedsdebat, og skolegymnastikken stod centralt $i$ indførelsen af det moderne samfunds sundhedssyn. Gymnastikken i skolen kunne sikre ungdommen et stærkt og rent legeme i såvel fysisk som psykisk henseende. Et rent legeme var også betingelsen for et ædelt indre og for at bevare sin sunde fornuft:

„Ej heller kan den, som forsømmer sit Legeme ved ikke at holde det fuldstandigt rent, vente at have rene, cedle Tanker. Naar man ikke sørger for at bevare sin Hud $i$ sund Tilstand, kommer Orga- 
nismen ikke af med de Gifte, som dette Organ efter bestemmelsen skulde skaffe af Vejen. Giftige Affaldsstoffer, som ikke udskilles fores rundt til alle Dele af Legemet og forgifter ogsaa Hjernen, som jo er Tankens Sted ${ }^{80}{ }^{8}$

Fra århundredskiftet til 1960-erne blev skolegymnastikken regelmæssigt berømmet for sin evne til at styrke, hærde og disciplinere sine udøvere samt forbedre deres sans for renlighed og hygiejne. Men det var ikke kun egenskaber, som skolefolk tillagde skoleidrætten, det var også egenskaber, som ledere indenfor såvel sportens som gymnastikkens verden tillagde deres aktiviteter.

Eksemplerne indenfor skolegymnastikken er legio. I århundredets første årti var debatten præget af en tro på, at gymnastikken og hygiejnen ikke alene var udtryk for legemlig, men også sjælelig sundhed. Fra slutningen af 1930-erne argumenteredes for, at den legemlige opdragelse burde opprioriteres af hygiejniske og sundhedsmæssige årsager. ${ }^{81}$ Lignende eksempler kan uden besvær findes også i de andre miljøer. Idrættens-gymnastikkens-sportens-skolegymnastikkens betydning for sundhed og hygiejne var ifølge de respektive tilhængere stor, den lærte sine udøvere gode vaner og disciplin. Disciplinen var vigtig og blev tit fremhævet som en positiv konsekvens af at dyrke såvel sport som gymnastik. Men hvor man omkring århundredskiftet ofte fremhævede skoleidrætten p.g.a. dens evne til ydre disciplinering af eleverne, skiftede holdningerne noget i løbet af 1920erne og 30erne. Nu blev skolegymnastikkens force snarere set i dens påståede evne til at opøve selvkontrol hos eleverne over kroppen og de funktioner og sammenhænge denne indgik i. På samme måde som det var tilfældet med sportsbevægelsen, var skolegymnastikken nu blevet et led i et bredere civiliseringsprojekt af den danske befolkning, hvori en række institutioner og »reformatorer« indgik. Reformatorerne kom især fra borgerskabet. ${ }^{82}$ I de nordiske lande, blev hovedparten af idrættens topledelse i mange år rekruteret fra borgerskabet. ${ }^{83}$ Især to grupper - læger og officerer - var særligt aktive som reformatorer. Indenfor sporten sammen med forretningsmænd og i skolegymnastikken sammen med pædagoger. ${ }^{84}$ Samfundets absolutte overklasse, adelen, var derimod næsten ikke aktiv ved sportens og skolegymnastikkens etablering. I Sverige var der meget få, i Danmark ingen repræsentanter fra adelen i den tidlige idrætsledelse. Heller ikke gejstligheden var repræsenteret. ${ }^{85}$ Såvel adel som gejstlighed har ved andre lejligheder spillet hovedroller som samfundsreformatorer i de nordiske lande. ${ }^{86}$

Slutningen af forrige århundrede var en opbrudstid, hvor hidtil gældende kulturelle, sociale og politiske normer og holdninger stod til diskussion, nye ideologier opstod, og arbejderklassen begyndte at gøre sig gældende som politisk kraft. Ikke mindst det voksende arbejderproletariat på land og i by, der oven i købet var begyndt at organisere sig, sås som en større og større trussel mod det etablerede system. En nærliggende løsning var at »tæmme« arbejderklassen ved at forandre den moralsk i retning af de dyder, der for længst var accepteret af borgerskabet selv. Værdien af kernefamilien, hjemmet og et moralsk liv blev fremhævet igen og igen via skole, massemedier og veldædige institutioner. ${ }^{87}$ Men der lå ingen overordnet plan bag dette forsøg på at vinde arbejderklassen for et moralsk borgerligt levned, for et godt liv. Disse værdier var indarbejdet og sad som instinkt hos reformatørerne selv, 
der så sig som missionærer for et bedre liv, for fremskridt og social udvikling. De ville forbedre bolig, madvaner, renlighed, sundhed og børneopdragelse hos mindre heldige samfundsgrupper. Mange fra borgerskabet var lykkeligt uvidende om, at deres reformiver havde et skjult moralsk budskab. De var den førende politiske, sociale og kulturelle kraft, og de forsøgte bare at indrette verdenen som den bedste af alle verdener, nemlig deres egen. Indretningsmodellen er ikke ukendt: Alt det, der afviger fra normen, forsøger samfundet at rette op på med afretning, fx ved hjælp af undervisning, behandling, regler og love. Disciplineringen er blevet stadig mere forfinet $i$ årenes $1 \varnothing \mathrm{b}$, og befolkningen underkaster sig frivilligt regler og kontrol. Mange former for regelsætning opfattes ikke længere som tvang, men er blevet internaliserede og dermed blevet en del af befolkningens sædvanlige adfærd. ${ }^{88}$

Det var dog ikke således, at alle fra borgerskabet var interesserede i idræt ved århundredskiftet, det var faktisk kun de færreste. Mange tog direkte afstand fra den slags upassende, svedige, uestetiske og barnlige aktiviteter. Det var iøvrigt ikke det eneste område, hvor der kunne være divergerende opfattelser indenfor borgerskabet. ${ }^{89}$ Nogle af borgerskabets medlemmer var imidlertid interesserede i gymnastik og sport. Så på samme måde som man kunne være fanatisk modstander af idræt i det hele taget og alligevel være fra borgerskabet, så kunne man også være idrætstilhænger fra borgerskabet, men foretrække svensk gymnastik frem for sport eller sport frem for svensk gymnastik. Men uanset om man foretrak sport eller gymnastik, havde man noget tilfælles. For det første kom - som nævnt - så godt som alle, der stod bag sportens eller skolegymnastikkens indførelse fra borgerskabet. ${ }^{90}$ For det andet til- lagde reformatorerne/lederne fra disse forskellige miljøer deres respektive aktiviteter de samme egenskaber. Sidstnævnte forhold har stor betydning, når man skal forstå dannelsen af den sundhedsdiskurs, som periodens idræt må ses i. I gymnastikkens og sportens begrundelser for deres respektive fordele fandtes en fælles kerne, der bestod af centrale borgerskabsdyder: Både sport og svensk gynmnastik var godt for sundhed, hygiejne og disciplin. Reformatorerne fra begge lejre tillagde deres aktiviteter de samme basale nytteværdier. Og de kæmpede de samme kampe.

I den danske sportsbevægelse havde »reformatorerne« mindst lige så »travlt« som i skolesystemet. Ideologi og normer med hensyn til hygiejne, præcision, påklædning og adfærd blev overført til arbejderklassen, der jo især var den klasse, der ikke kendte de borgerlige koder. ${ }^{91}$ Overførelsen indenfor sportens verden skete bl.a. via amatør- og ordensreglerne. ${ }^{92}$ Disse regler udviklede sig naturligvis, men hovedingrediensen var en interesse for ordensregler både indflettet i eller som tillæg til amatørreglerne. Mest tydeligt kommer denne bestræbelse til udtryk ved at ordet professionel udelades og erstattes af begrebet »ikke-amatør «. ${ }^{93}$ En »ikke-amatører« var enten en egentlig professionel i traditionel forstand eller en, der overtrådte »etiske regler «. De etiske regler udelukkede derimod også, hvis idrætsudøveren f.eks. var »berygtet i den offentlige mening«, »havde gæld «, »opførte sig dårligt«, »fornærmede en dommer eller leder «, »kritisere sin idrætsorganisation offentligt« eller var »upassende klædt«. Skete det kunne man miste sin amatørstatus og dermed blive udelukket fra at dyrke idræt. ${ }^{94}$ Egentlig » $\varnothing$ konomisk« professionalisme var uhyre sjælden og omfattede mindre end $2 \%$ af de, der blev udelukket af amatør- og ordensud- 
valget. ${ }^{95}$ Man blev især udelukket for ikke at opføre sig ordentligt.

I skolen blev man ikke udelukket, men straffet hvis man havde problemer med at opføre sig ordentligt, men også her blev kampen for bedre hygiejne i skolesammenhæng, ført på flere fronter især, idrætspåklædning og badning. Det var fuldstændig det samme billede som indenfor sporten. Allerede i 1898 og mange gange senere kunne lægen Clod-Hansen påpege, at nogle idrætsmænd brugte det samme (uvaskede) idrætst $\varnothing j$ en sæson ad gangen, hvis de klædte om, og at de sjældent gik i bad efter idrætsudøvelse. ${ }^{96}$ I 1917 kunne Knudsen med baggrund i gymnastikinberetningerne fastslå, at mange forældre nægtede at købe gymnastiktøj og sko til deres børn, ja end ikke ville tillade at de tog træskoene af, når de dyrkede gymnastik. Ministeriet påbød dernæst $i$ et cirkulære, at børnene skulle være iført gymnastiksko, og at kommunen skulle »anskaffe sko i forskellige passende størrelser «. ${ }^{97}$ Året før havde en gymnastiklærer skabt debat ved at påpege, at piger og kvinder altid brugte gymnastikdragt, men at drenge og mænd bare brugte deres almindelige klæder. Han påpegede desuden at: »Gymnastik og vandbad er jo desværre ikke stillet i nogen forbindelse med hinanden ved vore skoler $\ll .{ }^{98}$ Det man kunne tilbyde de fleste steder var kun svedaftørring og luftbad.

Kravet om god kropshygiejne indebar hos borgerskabet grundige og regelmæssige afvaskninger af hele kroppen. Kultiverede personer badede dagligt eller mindst en gang om ugen. På landet fandtes smuds overalt, det var en del af hverdagen og ikke en trussel. Omkring århundredskiftet var det ikke almindeligt i store dele af landbobefolkningen, at man gjorde rent $\mathrm{i}$ hjemmet som en rutine, men kun når man gik fra hverdag til fest. Man vaskede sig sædvan- ligvis kun en gang om ugen og kun på de dele af kroppen, der kunne ses. Der var nok at tage fat på for en »reformator « på højskolen, i gymnastikforeningen eller i skolen. I byerne var det fysiske miljø med de ofte rystende boligforhold i sig selv en hindring for arbejdernes hygiejne. For de fleste arbejdere var det svært at leve op til borgerskabets normer, men mange - først og fremmest blandt de faglærte - forsøgte at stræbe mod den finere verden, hvor menneskene var beherskede, ordentlige og rene. Via ideerne om hygiejne overtog og tillempede dele af arbejderklassen de borgerlige holdninger. Renlighed, kontrol og selvdisciplin kom til at gå hånd i hånd. ${ }^{99}$ Lys, luft og renlighed blev via borgerskabet til et generelt opdragelsesprogram for de lavere klasser. Et program autoriteter og reformatorer, også indenfor sporten og gymnastikken, var fælles om. Det var en folkesag.

Reelle fremskridt i skolen indenfor hygiejnens og sundhedens område blev som tidligere antydet - vanskeliggjort af de dårlige eller manglende faciliteter. Ude på landet stod spyttebakken med tuberkolosebakterierne stadig ved siden af kakkelovnen. ${ }^{100}$ Men i den nybyggede skole i byen blev gulvet gjort rent med svabning efter hver time. Der var udluftning, adgang forbudt for udesko og brusere, der af læreren kunne indstilles individuelt til de anbefalede 18-38 grader C. Og op imod anden verdenskrig var man ved de nye skoler yderligere nået så vidt, at hver klasse havde en stang med bøjler, så hver elev havde sin egen til dragt og sko. Ordensduksene sørgede for i frikvarteret før timen at anbringe hver elevs bøjle på den for eleven bestemte ribbe. Man kunne så gå nøgen fra omklædningsrummet ind i salen og der iføre sig dragten. ${ }^{101}$ Modsat, når timen var forbi. Dermed var indført en slags sluse, 
der kunne holde sygdomsbakterier ude af gymnastiksalen. Orden og hygiejne gik også hånd i hånd.

Kampen mod sygdom og for sundhed og hygiejne var nemlig i høj grad et ordensprojekt. At klassificere verden, ordne den efter det system, som man har lært sig, indebærer, at man udskiller det som ikke passer. Kampen mod urenlighed og uorden er den klassiske kamp mod kaos. Urenhed er noget, som ikke er på sin rette plads. Renhed har med orden og urenhed har med uorden at gøre. Trangen til at skabe orden i bred forstand giver sig udtryk i en vilje til at udøve magt. »Viljen til magt er en ordensmagt, idet der søges et gentageligt mønster, som forsikrer om ro og orden, og som dermed virker betryggende $\ll .{ }^{102}$ Borgerskabets ordensmagt i denne sammenhæng er således viljen til på det sociale niveau at bekæmpe, at forbyde det der falder udenfor den sociale orden, der konstituerer borgerskabet. Det, vi tager afstand fra, tilskriver vi egenskaber som smudsigt, ækelt og urent. Hvad, vi tager afstand fra, beror imidlertid på den kultur vi er opvokset i, de erfaringer vi har gjort, og de kundskaber vi er blevet bibragt. ${ }^{103}$ Ved at betone sin egen ordentlighed $\mathrm{i}$ alle livets forhold - og gøre den til dyd - kan man markere et højere udviklingsstade:

»Den borgerlige kultur blir den rette vinkels og den klare funktionsopdelings kultur. I det borgerlige hjem var man besat af at trakke granser mellem forskellige aktiviteter og territorier. B $\phi r n$ afgranses fra voksne, familien fra tjenestefolk, det private fra det offentlige..... Samme ordningsprincip ser vi i organisationen af den borgerlige offentlighed. Den rette vinkels princip går igen i sygesengenes eller skolebonkenes snorlige rakker ... I alle disse tilsyneladende trivielle detaljer foregår en konstant kamp mod et truende kaos. ${ }^{104}$

Kultur og orden lænkes sammen i modsætning til natur og kaos. Grænser trækkes.

Kaos blev yderligere bekæmpet gennem gymnastiksalens indretning og gymnastikkens indhold, der hver for sig søgte at overbevise om, at her herskede orden og regelmæssighed. Det sås i standardiserede og reglementerede redskaber hver med sin rette plads, når de ikke var i brug. Det sås i den måde tove og ringe hang - og hænger - $\mathrm{i}$ velordnede bundter i symetriske mønstre. Det sås i marcheren i takt, snorlige rækker, $\emptyset$ velser i samtidighed. Det sås i den ivrigt kontrollerende lærerautoritet, der fulgte forskrifterne fra København. Det sås ikke mindst $\mathrm{i}$ indholdet af de $\varnothing v e l s e r$, der blev gentaget $\mathrm{i}$ det uendelige til perfektion og mange gange brugt $\mathrm{i}$ årevis. Og det sås ikke mindst $\mathrm{i}$ instruktionsbøgernes kælen for detaljen samt søgen efter præcision i formulering og udførelse af den enkelte øvelse. En søgen der ofte blev ført helt ud i det absurde. F.eks. som i denne øvelse: ${ }^{105}$

»Spring fremad med delt Aftryk uden Till $\phi b \ll$.

$»$ Til Spring fremad, venstre Fod bagudsat! Spring! «

„Paa sat flyttes venstre Fod under Ottendedelsvending til venstre et Skridt bagud, begge Kno bøjes, bagerste mest (Dakstilling), Kroppen vendes (effaceres), saa at Brystet viser lige til Siden, Ansigtet lige fremad. Paa Spring tages der kraftigt Aftryk forst med bagerste, derpaa med forreste Fod; Kroppen vendes herunder frem i Springets Retning, Armene svinges fremad, Fødderne samles, Kroppen rettes, og Nedspring g $\phi$ res.«« 
Aktiviteterne i gymnastiksalen og på sportspladsen blev ustandselig fulgt af reformatorerne, der $\mathrm{i}$ et væld af bøger og artikler dels agiterede for at dyrke idræt, og dels havde gode råd til dem der allerede var igang. De måtte efterkomme et levesæt med tilstrækkelig søvn, fornuftige kostvaner, mådehold overfor nydelsesmidler som alkohol, tobak og kaffe. Men kunne samtidig glæde sig over, at såvel gymnastik som sport styrkede moralen, mindskede ungdomskriminaliteten og nedsatte den seksuelle trang i pubertetsårene. ${ }^{106}$

\section{Skoleidratten ca. 1900-1960}

Interessen for sundhed, hygiejne, adfærd, disciplin og orden hos reformatorerne $\mathrm{i}$ skolegymnastikken og sporten var manifest. Disse begreber var generelt i perioden 1900-1960 vigtige instrumenter i overførelsen af borgerskabets normer til den $\emptyset$ vrige del af befolkningen. Overførelsen der ikke var resultat af en bevidst formuleret strategi eller plan - fandt i skolesam- menhæng sted i det indhold, man gav skoleidrætten, og i den måde man organiserede den på. I skoleidrætten var gymnastik i hele perioden frem mod 1960 den vigtigste aktivitet. Sport og leg blev dog aldrig holdt ude og havde sin store - efter mange gymnastikfolks mening for stor - rolle i skoleidrætten. Der var aldrig tale om indførelsen af en ægte svensk gymnastik i skolen, men en række »svenske principper « blev opstillet og søgt udbredt. Allerede omkring første verdenskrig blev indholdet i den såkaldte svenske gymnastik ændret, idet stillingsgymnastikken efter inspiration fra bl.a. Niels Bukh og Elin Björksten blev afløst af en gymnastik med mere bevægelse og tempo. At piger og drenge blev ligestillet m.h.t. at blive undervist i skoleidræt fra århundredskiftet er en myte, idet det først var tilfældet omkring 2. verdenskrig. Undervisningen var mange steder især på landet - men ikke kun der - præget af dårlige faciliteter, ringe uddannede lærere og manglende entusiasme hos myndigheder, forældre og elever.

\section{Noter:}

1.Når begrebet »Moderniseringen« anvendes i denne artikel dækker det perioden ca. 18801960. I den periode må den politiske, sociale og kulturelle udvikling i Danmark i stort omfang ses $i$ en sundhedsdiskurs, mens den tilsvarende udvikling efter ca. 1960 må ses i en velfærdsdiskurs. Et tilsvarende begreb, »Det moderne gennembrud «, er almindeligt anerkendt i Danmark som en samlet betegnelse for de kulturelle og politiske kampe, der i perioden ca. 1880 til 1920, ændrede Danmark gennemgribende. Sportens rolle i Danmark i den periode er beskrevet i Per Jørgensen: Ro, Renlighed, Regelmassighed, Odense 1997.

2. Jørn Hansen og Niels Kayser Nielsen, »Krop, Idræt, Sundhed 1870-1930« i Den jyske Historiker nr. 72 (Århus, 1995) pp. 70-74,76.
3. Jørn Hansen, »Legems øvelser som universitetsstudium « i Fra kaos til mangfoldighed (Odense, 1995) p. 14.

4. Disse antagelser findes helt eller delvist i det meste af den litteratur, hvor dansk skoleidræt i det 20. århundrede beskrives. Mest tydeligt hos: K.A. Knudsen: Danmarks Hфjskole for Legemsфvelser 1898-1948, København 1948, Ernst Møller: Træk af skoleidrættens historie i Danmark, Nyborg 1980 og Ove Korsgaard, Kampen om Kroppen, (København, 1982). Dele af denne fremstilling er dog blevet nuanceret af Per Fibæk Laursen: Idrætsdidaktikkens Modernisering, København 1995 samt af Ivar Berg-Sørensen og Per Jørgensen (red.): »Een Time Dagligen - skoleidræt gennem 200 år« København, 1998.

5. Denne udviklings baggrund og forl $\varnothing \mathrm{b}$, kommis- 
sionernes arbejde og striden mellem tilhængere af »svensk « respektiv »dansk « gymnastik skal ikke beskrives her. Der henvises især til Else Trangbæk: Mellem Leg og Disciplin, Aabybro 1987.

6. Indførelsen af Ling-gymnastikken i Danmark i højskole-, gymnastik- og skyttebevægelse samt sidenhen i skolesystemet, set i lyset af den særlige politiske og kulturelle kamp mellem partierne »Venstre« (opposition) og »Højre« (regering), er et velbeskrevet tema i den danske idrætshistorie. Der henvises især til Ove Korsgaard: Kampen om kroppen, (1982) op.cit.

7. Denne institution fik i 1911 navneforandring til »Statens Gymnastikinstitut«, (»Gymnastikinstituttet«) og igen i 1940 til Danmarks Højskole for Legemsøvelser (DHL), der i 1997 indgik i »Institut for Idræt, Københavns Universitet«.

8. K.A. Knudsen (1864-1949) var leder af Statens Et-aarige Gymnastikkursus 1898-1911 og af efterfølgeren, Statens Gymnastikinstitut 19111927. Yderligere var han Statens Gymnastikinspektør 1904-1935.

9. Ved reformen i 1958, blev gymnastik frataget sin dominerende stilling. Faget kom nu officielt til at hedde legemsøvelser, og i løbet af de næste 1015 år blev gymnastik en aktivitet blandt flere og flere. Ved en senere reform, i 1975, fik faget sit nuværende navn, »idræt «. Allerede i undervisningsvejledningen (1941) blev faget kaldt »Legemsøvelser«. Undervisningsvejledning for den Eksamensfri Folkeskole« (København, 1941).

10. Se f.eks. Ove Korsgaard, Kampen om Kroppen (1982) op.cit. p. 178.

11. Henrik Meinander, Towards a Bourgeois Manhood (Helsinki, 1994) p. 110

12.»Haandbogen i Gymnastik«, København, 1899 (p. 281)

13. Principperne er opstillet med udgangspunkt i K.A. Knudsen, Danmarks Højskole for Legemsфvelser (København, 1948) og Haandbogen $i$ Gymnastik (Kфbenhvn, 1899) (op.cit.)

14. Per Jørgensen: »Ikke at More, men at Opdrage« i: Ivar Berg-Sørensen og Per Jørgensen: Een Time Dagligen (København, 1998) p. 89.

15. Ibid. pp. 89-90

16. Ibid. pp. 89-90 og112. Hvert år blev der indsamlet statistiske oplysninger om tilstanden i den danske skole. Blandt de mange oplysninger om gymnastikkens almene tilstand kunne man år efter år finde en optegnelse over, hvor mange bomme, fag ribber, bukke og plinte der eksisterede i den danske skole. Sammenholdes disse tal med antallet af skoler, kan man finde frem til, at der f.eks. i 1910, i gennemsnit var mindre end 5 sæt ribber, 1,5 bom, $2 / 3$ buk samt $1 / 2$ plint i de danske skoler. Femten år efter, i 1925, var disse tal kun forbedret med ca. 20\%. Det var især landsbyskolerne, der manglede redskaber. Også det forhold, at der kendes til klassestørrelser på op til 70 elever, tilgodeså stillingsgymnastik, der jo ikke er specielt pladskrævende.

17.F.eks. i Sverige fra 1882, Jan Lindroth, Idrottens väg til folkrörelse (Uppsala, 1974).

18.18 I Sverige var der således uenighed mellem Ling-gymnastikken og sporten. Det samme var tilfældet i Danmark, hvor uenigheden ligefrem er blevet udnævnt til at være et kernepunkt i forståelsen af idrættens almene udvikling (se f.eks. Ove Korsgaard, Kampen om kroppen, (1982) op.cit. I Danmark var forholdet mellem sporten og den frivillige skytte- og gymnastikbevægelse, der også var præget af Ling-gymnastikken, imidlertid ofte kendetegnet ved samarbejde og fordragelighed. Det var derimod især de ledende pædagoger i skolen, hvor Linggymnastikken også havde en stærk bastion, der havde forbehold overfor sporten. Per Jørgensen, Dansk Idratsliv (København, 1995) bd.1. I Sverige var det også især lingtilhængerne i skolen, der angreb sporten, idet linggymnastikken først og fremmest blev udøvet der og ikke i den frivillige idræt. Jan Lindroth, Idrottens väg till... (1974) op.cit.

19. Pierre de Coubertin, Olympic Memoirs (Lausanne, 1975) p. 23.

20. John J. MacAloon, This Great Symbol: Pierre de Coubertin and the Origins of the Modern Olympic Games (Chicago, 1981) p. 169

21.Per Jørgensen, »Order, Discipline and Self-Control - The Breakthrough for the Danish Sports Federation and Sport 1896-1918 «, The International Journal of the History of Sport. Vol 13, No.3 (Dec. 1996) p. 340.

22. Korsgaard Kampen om kroppen op.cit. (1982) p. 175.

23. W.Hougaard, Sport (København, 1988) p. 33.

24. Per Jørgensen (1998) Ikke at More, men at Opdrage op. cit. p. 120. Der blev dyrket mere sport udenfor København end i København allerede før århundredskiftet. Per Jørgensen Ro, Renlighed, Regelmæssighed (1997) op.cit. pp. 251-260.

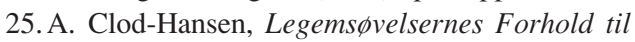
Aandelig Overanstrangelse sarlig med Hensyn til Skolen« (København, 1892) p. 23.

26. Herbert Sander, Dansk Idrat gennem 50 Aar (København, 1946) pp. 66-67. 
27. Dansk Idræts-Forbunds Aarsberetning, 1921 (København, 1922) Bilag D.

28. Denne beslutning var iøvrigt delvis inspireret af en beslutning i Tyskland året før. Et cirkulære af lignende indhold blev afsendt i juni 1897, ikke til skolerne, men til seminarierne. Per Jørgensen (1998) Ikke at More, men at Opdrage (op.cit.) p. 94.

29. K.A. Knudsen, Danmarks Højskole for Legemsфvelser 1898-1948 (København, 1948). p. 165.

30. Per Jørgensen (1998) Ikke at More, men at Opdrage (op.cit.) p. 94.

31. Således måtte en ministeriel bekendtgørelse i november 1915 og en ny i 1917 advare skolerne mod, at gymnastiktimerne i større omfang end ønskeligt anvendes til boldspil. Herefter måtte boldspil kun finde sted i tiden fra 15. april til 10. oktober og ikke i større omfang end at der også i samme tid øvedes gymnastik mindst 1 time ugentlig. Hermed var gymnastikken sikret - i det mindste på papiret - 3/4 af tiden til skoleidræt. »Undervisningsministeriets Cirkulare til samtlige Skoledirektioner uden for Kфbenhavn af 17de April 1917 « samt Ernst Møller, Trak af skoleidrattens historie i Danmark (Nyborg, 1980) pp. 22-23.

32. Haandbog i Gymnastik (1899) op.cit. p. 284.

33. Ibid p. 278.

34. Ibid. p. 278.

35. Ibid. p. 279.

36. Korsgaard, Kampen om kroppen (1982) op.cit. p. 249.

37. Frederik Knudsen, Skolebørnenes Legebog (København, 1908), Dansk Legebog (København 1915), Larebog i Lege og Boldspil (København, 1918).

38. Frederik Knudsen var f.eks. langt fra modstander af svensk gymnastik. »Legen « udfordrede således ikke den svenske gymnastik på samme måde som sporten, der jo tit blev angrebet af »svenskerne for at indeholde stort set de samme elementer, som legen indeholdt. Det må dog også med, at selv svorne tilhængere af svensk gymnastik, som f.eks. K.A. Knudsen som nævnt ikke nødvendigvis var modstander af leg og boldspil. Han roste iøvrigt ved flere lejligheder Frederik Knudsen såvel som lærer som for hans indsats for leg og boldspil. Frode Andersen, »Fra gymnastik til legemsøvelser« i Emanuel Hansen, Danmarks Hojskole for Legemsфvelser 19111961 (København, 1961) op.cit. pp. 43-52.

39. Ernst Møller, Trak af skoleidrattens historie $i$ Danmark (København,1980) p. 117.

40. Ibid. pp. 157-158.
41. Det første blev arrangeret af OL-deltageren fra 1896, den senere rektor for DHL (1927- 1930), Holger Nielsen fra Ordrup Real- og Latinskole. De følgende af Dansk Gymnastik-Forbund. Men fra 1904-1911 blev der ingen afholdt, måske p.g.a. kontroverser mellem svensk skolegymnastik og dansk gymnastik, som den blev udøvet i DGF. Per Jørgensen, Ikke at More, men at Opdrage (1998) op.cit. pp. 123-125.

42. Ernst Møller, Trak af Skoleidrattens historie (1980) op.cit. pp. 112,113,117.

43. Per Jørgensen, »Idræt under forandring « i Bjarne Ibsen m.fl. Idrat i bevagelse (København, 1993 (2. oplag)) p. 47.

44. Ibid. pp. 46-50.

45. Principper fra den svenske gymnastik kan genfindes i idrætsmærket $\mathrm{i}$ et ligesidighedskrav, der krævede, at både venstre og højre hånd skulle bruges i f.eks. kast. Der var også forskel på kravene til pigerne og drengene. Ikke kun i form af de sædvanlige kvantitative krav, men også kvalitative. Hvor drengene f.eks. skulle kaste så langt som muligt, skulle pigerne kaste til måls. Skoleidrætsmærket, der således som megen anden idræt både repræsenterede og producerede et idrætssyn, blev efter 2 . verdenskrig lavet om til et rent atletikmærke. Det skete først for drengene og i begyndelsen af 1950-erne også for pigerne. Ibid. samt Per Jørgensen, »»Fra at vakke lyst « til »at give tilbud « - Idratsmarkets historie 19221997« (København, 1996).

46. Allerede i december 1900 kom cirkulære i »Vejledning i brug af Haandbogen i Gymnastik af 1899 «, hvor det bl.a. blev slået fast, at det var obligatorisk for gymnastiklærere at udarbejde timeseddel. I samme cirkulære blev det yderligere fastslået, at »Skolegymnastikken skulle opbygges i overensstemmelse med »Lovene for Menneskelegemets Livsytringer.« Hver enkelt øvelse skulle være sund og udviklende for barnet. Om målet blev nået kunne ses i barnets holdning. Kravene om øget kvalitet i skolegymnastikken både i forhold til indhold, lærere og faciliteter fortsatte i de følgende år. I 1901 blev det gjort pligtigt for lærerne at føre en gymnastikbog, hvori de skulle notere, hvilke øvelser de brugte i hver enkelt time. Per Jørgensen, Ikke at More, men at Opdrage (1998) op.cit. pp. 95-97.

47. K.A. Knudsen, Timesedler til Brug ved Gymnastikundervisningen for mandlige Elever (Кøbenhavn, 1900) samt Timesedler til Brug ved Gymnastikundervisningen for kvindlige Elever (København, 1900). 
48. Per Jørgensen, Ikke at More, men at Opdrage (1998) op.cit. p. 97.

49. Ibid. p. 97.

50. Ibid. p. 97.

51. Ibid.p. 119.

52. Indberetningerne findes på Rigsarkivet i København.

53. Ove Korsgaard, Kampen om kroppen (1982) op.cit. pp. 179-180.

54. Per Jørgensen, Ikke at More, men at Opdrage (1998) op.cit. p. 117.

55. Ibid. p. 116.

56. Ove Korsgaard, Kampen om kroppen (1982) op.cit. p. 197.

57. Inspektionen bragte dog også sine solstrålehistorier, hvor lærere selv under dårlige forhold formåede at inspirere eleverne og undervise på højt fagligt niveau. Således fik en lærer på Sydsjælland megen ros, fordi han på en umulig gymnastikplads fik børnene - såvel piger og drenge engagerede i leg og boldspil. Beretning om Statens kursus (København, 1908) p. 34.

58. Per Jørgensen, Idrat under forandring (1993) op.cit. p. 43.

59.Beretning om Statens Gymnastikinstitut 1925 (København, 1926) pp. 51-56.

60. Oprindelig, hedder det sig, blev skolegymnastik indført for begge køn allerede ved skoleloven i 1814. I 1828 blev den dog afskaffet for piger. Men heller ikke i 1814 var skolegymnastikken imidlertid blevet gjort obligatorisk. Det var den iøvrigt hverken for piger eller drenge! Det fremgår tydeligt af den kongelige anordning, at kun hvis lærerne var seminarieuddannede med gymnastik som fag, eller på anden vis havde skaffet sig en tilsvarende duelighed, skulle der undervises i »gymnastiske Øvelser«. Anordning for Almue-Skolevasenet paa Landet i Danmark af 29. Juli 1814: »I de Skoler, hvor Lærere, der ved de af Os allernaadigst autoriserede Skolelærer-Seminarier have nydt Underviisning i Gymnastik eller paa anden Maade have erhvervet sig den Duelighed, som udfordres til deri at give Underviisning, ere ansatte, skulle Børnene veiledes af Skolelærerne til gymnastiske Øvelser, saasom Løbe-, Springe-, Klavre-, Svømme- og militaire $\emptyset$ velser $\ll$.

61. I »Forskolen« skulle eleverne i følge Lov om forskellige Forhold vedrorende Folkeskolen (29.3.1904): »øve en for deres Alder afpasset Gymnastik med lege«. I de øvrige klasser kunne man i Købstæderne, hvis forholdene talte herfor, få tilladelse til, at: »Indførelsen af Gymnastik for
Pigerne foreløbig udsættes«. På landet skulle der gives undervisning i gymnastik til drengene. Man måtte dog også gerne give pigerne undervisning, men det var intet krav (paragraf 10).

62.Lov om folkeskolen af 18. Maj 1937 (nr. 160), (paragraf 16-19).

63. Thomas Skovgaard og Charlotte Worm, Fra den gode til den funktionelle holdning? (Odense, 1997 (speciale) p. 73.

64. Beretning om Statens Kursus i Gymnastik 1911 (København, 1912) pp. 36-39.

65.Beretning om Statens Gymnastikinstitut 1925 (København, 1926) pp. 51-56.

66. Johannes Lindhard, »Hr. Niels Bukh's Opvisning i Koncertpalæet 1. April 1917« i Akademisk Gymnastik (København, 1919) p. 47.

67. K.A. Knudsen, Statens Gymnastikinstituts årsberetning, 1912 (København, 1912) p. 14.

68. Johnny Wøllekær, »... I et sundt legeme eller? «en analyse af mellemkrigstidens idrat-og sundhedsdiskussion (Odense Universitet, Institut for Idræt - eksamensprojekt, 1992) p. 7.

69. Per Jørgensen, Ikke at More, men at Opdrage (1998) op.cit. p. 133.

70. Johannes Lindhard, Den specielle Gymnastikteori (København, 1926) p. 152.

71. Erling Asmussen, Gymnastikstudiet og det gymnastikteoretiske laboratorium ved Kobenhavns Universitet (København1987) pp. 31-32.

72. Per Fibæk Laursen, Idratsdidaktikkens modernisering (København,1995) pp. 272, 273.

73. Ove Korsgaard: Kampen om kroppen opus, Gil og Per Jørgensen, Ikke at More, men at Opdrage (1998) op.cit. p. 136.

74. Per Fibæk Laursen, Idratsdidaktikkens modernisering (1995) op.cit. p. 266.

75.Per Jørgensen, „From Balck to Nurmi: The Olympic Movement and the Nordic Nations « i: The international Journal of the History of Sport (14-1997) p. 75

76. Det hed sig, at idrætten opbyggede muskulaturen, den forhindrede nedsættelsen af bevægeligheden i led og muskler. Desuden udviklede idrætten hjertets størrelse og fald af »Pulstallet«. Tilsammen gav idrætten et »kraftigere, mere veludviklet Legeme set som en Helhed «. »Idrætten danner et nødvendigt Led i det moderne Samfunds Hygiejne. Anvendt paa rette Maade er den sund, respektive helbredende og forebyggende « Knud Secher, »Legemsøvelser og Sundhed« i Dansk Idrat 1931 (København, 1931) pp. 195-200.

77. Johannes Lindhard, »Gymnastik og Sundhed« i Vor Ungdom (årgang 53) pp. 20, 21. 
78. Niels Kayser Nielsen, »Hälsa och idrott - en modern och nationell angelägenhet « i: Svensk Idratshistorisk Forenings Arsskrift, (1994) pp.6184.

79. Lars Henrik Schmidt og Jens Erik Kristensen, Lys. Luft og Renlighed (København, 1986) pp. 70-75.

80. Sundhedsbladet 22. årg. 1902, (København, 1902) p. 221.

81. Ibid. pp. 69-71.

82. Borgerskabet fik i løbet af det 19. årh. en stadig mere dominerende indflydelse og fremstod allerede før århundredskiftet som den førende klasse politisk, kulturelt og socialt i Norden. I borgerskabets opdragelse blev en række normer, holdninger og forventninger indpræget. Det borgerlige menneske var disciplineret og kontrolleret, og dets kultur var blevet normgivende for andre grupper i samfundet i by og på land. På den ene side distancerede det borgerlige miljø sig fra disse grupper, på den anden side forsøgte det at reformere deres vaner og ideer. Per Jørgensen, Ro, Renlighed, Regelmassighed (Odense, 1997) pp. 61-93.

83. Ibid.pp. 246-249.

84. Ibid. pp. 246-249 og Jørn Hansen, »Gennembruddet: Fra Sundhedskommissioner til Gymnastikkommissioner - ca. 1880-1904« i: Ivar Berg-Sørensen og Per Jørgensen Een Time dagligen (1998) op.cit. pp. 77-81.

85.Per Jørgensen, Ro, Renlighed, Regelmassighed (1997), op.cit. pp. 261-262, 271.

86. Det har de også indenfor områder som kultur, skole og fysisk uddannelse. Når de var fraværende $\mathrm{i}$ forbindelse med sportens etablering i de nordiske lande, er det, fordi denne etablering må ses som en del af det moderne gennembrud, hvor de nordiske lande, gennem en kulturel og politisk indsats »ført ind « i det 20. århundrede. Ikke mange repræsentanter for adel og gejstlighed var aktive i det moderne gennembrud. Ibid.

87.ibid. pp. 61-93.

88. ibid. pp. 61-93.

89. Selv synet på et af borgerskabets flagskibe, familien, kunne omkring århundredskiftet være anderledes hos officerer og højere embedsmænd end hos de nye grupper af industrifolk, købmænd og administratorer. Men ligesom synet på familien blev mere og mere homogent indenfor borgerskabet i tiden frem mod første verdenskrig, skete det samme indenfor områder som sundhed og hygiejne. Borgerskabet blev i årenes løb en sammensvejset klasse både socialt og kulturelt. Det er blevet påpeget, at udbredelsen af den borgerli- ge livsstil til bredere sociale lag resulterede $\mathrm{i}$, at udviklingen af den nordiske velfærdsstat efter anden verdenskrig i høj grad var præget af grundlæggende borgerlige værdier og normer. Afstanden og dermed »nedsivningshastigheden « mellem samfundets lag var blevet formindsket. Henrik Meinander, Towards a Bourgeois Manhood (1994) op.cit. p. 222 og Per Jørgensen, Ro, Renlighed, Regelmassighed (1997) op.cit. pp. 61-93.

90. Per Jørgensen, Ro, Renlighed, Regelmassighed (1997) op.cit. pp. 246-249 og Jørn Hansen, »Gennembruddet: Fra Sundhedskommissioner til ...« op.cit. pp. 77-81.

91.Per Jørgensen, Ro, Renlighed, Regelmassighed (1997) op.cit. pp. 61-93.

92. Ibid. samt Per Jørgensen, »Order, Discipline and Self-Control $\ll$ i: The International Journal of the History of Sport, vol. 13, No. 3 (1996) (op.cit.).

93. Sveriges Riksarkiv, Öfverstyrelsens protokoll AII-1, 25.11.1905.

94. ibid.

95. Per Jørgensen, Ro, Renlighed, Regelmassighed (1997) op.cit. pp. 205-239.

96. Abraham Clod-Hansen, »Om bade« i Dansk Idrats-Forbunds Aarbog, 1898 (København, 1898).

97. Ernst Møller, Trak af skoleidrattens historie (1980) op.cit. pp. 32-34.

98.ibid. pp. 28, 29.

99. I København kunne man omkring århundredskiftet finde mere end 1000 to-værelsers lejligheder med mindst otte beboere og uden toilet. Mange af lejlighederne havde ikke indlagt vand. Omkring 20\% af børnene døde inden de var tre år. Per Jørgensen, Ro, Renlighed, Regelmassighed (1997) op.cit. pp. 72-73.

100. Ernst Møller, Trak af skoleidrattens historie (1980) op.cit. pp. 29,30.

101. Ibid. pp. 35,36 .

102. Per Jørgensen, Ro, Renlighed, Regelmassighed (1997) op.cit. pp. 86-90.

103. Borgerskabets normer var konstituerende for god tone og korrekt adfærd. De lavere klassers måde at leve på var i den sammenhæng præget af kaos og uorden. Ibid. pp. 61-93.

104. Ibid. pp. 86-90.

105. Rikard Frederiksen, »Fra kommando til Undervisning « i Emanuel Hansen, Danmarks Hojskole for Legems $\phi$ velser (1961) (op.cit.) p. 65. Øvelsen blev brugt bl.a. på Statens Et-aarige Kursus.

106. Per Jørgensen, Ikke at More, men at Opdrage (1998) op.cit. p. 150. 